\title{
Mismatch and job mobility of married female migrant workers in China
}

\author{
Hu Weibin ${ }^{1}$ \\ ${ }^{1}$ The school of management, China Academy for Rural \\ Development,Zhejiang University
}

\author{
Han Hongyun 2,a \\ ${ }^{2}$ Corresponding author: R1316Qizhen Building, \\ Zhejiang University,310058,Hangzhou, China \\ âHongyunhan@zju.edu.cn
}

\begin{abstract}
A segmented labor market between rural and urban is an impediment to social transformation in China. Our empirical analysis indicates that marital stability via working at the same firm or city with their husbands is the main purpose pursued by MFMWs by virtue of job mobility, young and educated migrant women with low wages and labor-intensive jobs are more likely to change jobs. The majority of MFMWs employed in informal sector change jobs because of mismatch, which is reflected by shorter job tenure, the gap between real and expected wages, and occupations poorly matched with skill requirements of job openings. The segmentedlabor market in transitional China augments the intention of job mobility due to the weak connection between match quality and job experience and lack of job ladders.
\end{abstract}

Keywords: match quality; on-the-job search; married female migrant worker; job mobility

\section{Introduction}

During the process of social transformation in China, on-the-job search is prevalent and generates large flow of migrant workers due to segmented labor market in China. Married rural women accounted for $1 / 3$ to $1 / 2$ of total labor force in China, the purpose of the job mobility of married female migrant workers (Hereinafter MFMWs) is believed to maximize family interest. The impact of the female' role in taking care of dependent population on their employment has been a controversial issue for a long time in China. One view is that higher psychological costs have led to the low job mobility of female labors(Su\&Liu 2003); another opposing view is that the social status of the female forces themto change jobs more often as a subsidiary to family movement (Yao \& Hu 2009) and husbands. It is difficult to quantify match quality due to the lack of micro data.Hence, previous empirical studies based on broad historical observations fail to establish the micro mechanism of a job match, in further to explore the interaction of match quality and job mobility. The empirical relation between malfunction of labor market and job mobility has, I believe, received inadequate attention both in China and in the World. This paper contributes to the search-and-matching approach by combining a theoretical model of job mobility with an empirical analysis on the interaction of match quality and job mobility based on micro data.

This paper documents how labor turnovers systematically affect the rate of growth in wages both across jobs andwithin the job. It will be my working hypothesis to interpret the weak connection of wage growth with human capital accumulation by virtue of job mobility in transitional China. The remaining is divided into following sections. Section I develops a static model of volitional pragmatism of on-the-job seekers to explore the relationship between mismatch and the job mobility of MFMWs. Section II examines the empirical interaction between match quality and job mobility based on field surveyed data. Finally, it is a brief conclusion and policy implications for the improvement of labor market.

\section{Factors determining the job mobility of married female migrant workers}

\subsection{Factors affecting job mobility}

An on-the-job seeker engages in a search over a variety of employment possibilities by 
Table 1 Regression results

\begin{tabular}{|c|c|c|c|c|}
\hline & Variables & $\mathrm{B}$ & S.E & $\operatorname{Exp}(B)$ \\
\hline \multirow{17}{*}{$\begin{array}{l}\text { Factors } \\
\text { affecting } \\
\text { time } \\
\text { preference }\end{array}$} & Age (40 to 50 years old as the reference point) & & & \\
\hline & 20 29 years old & $7.519 * * *$ & 2.794 & 1843.327 \\
\hline & 30 39 years old & $4.392 *$ & 2.431 & 80.782 \\
\hline & Education level (0 5years as the reference point) & & & \\
\hline & $6 \sim 11$ years & $5.768 *$ & 3.167 & 319.810 \\
\hline & 12 years and above & 0.844 & 2.562 & 2.326 \\
\hline & Number of kids on hand (no kid as the reference point) & & & \\
\hline & Number of kids aging at 1 5years old & -0.154 & 2.537 & 0.857 \\
\hline & Number of kids aging at $6 \sim 10$ years old & -15.544 & 4641.281 & 0.00 \\
\hline & Number of kids aging at 11 years old and above & -0.670 & 1.695 & 0.512 \\
\hline & $\begin{array}{l}\text { Working location of her husband (at different city as the reference } \\
\text { point) }\end{array}$ & & & \\
\hline & Different firms in the same city & $-2.550 *$ & 1.365 & 0.078 \\
\hline & Same firm in the same city & $-7.337 * * *$ & 2.003 & 0.001 \\
\hline & Training (no training as the reference point) & & & \\
\hline & Training by firms & -1.933 & 1.208 & 0.145 \\
\hline & Training by training schools & $4.898 *$ & 2.776 & 133.995 \\
\hline & Training by government agencies & 18.909 & $\begin{array}{l}19553.12 \\
2\end{array}$ & $1630 \mathrm{E} 8$ \\
\hline \multirow[t]{5}{*}{$\begin{array}{l}\text { Search } \\
\text { channels }\end{array}$} & $\begin{array}{l}\text { Search channels of first job searching (through relatives and } \\
\text { friends as the reference point) }\end{array}$ & & & \\
\hline & Television and newspaper advertisements & $-4.861 * *$ & 2.038 & 0.008 \\
\hline & Government agencies & $7.679 * * *$ & 2.928 & 2162.916 \\
\hline & Professional intermediaries & 2.643 & 12.488 & 14.056 \\
\hline & First Job arrangement already before entering into cities & $-4.181 * * *$ & 1.479 & 0.015 \\
\hline Match & Working hours per day of the fist job & $1.485 * *$ & 0.611 & 4.413 \\
\hline \multirow[t]{12}{*}{ quality } & Whether sign a formal contract or not for the first job & -0.621 & 1.312 & 1.861 \\
\hline & Monthly wage of the first job & $-0.007 * * *$ & 0.003 & 0.996 \\
\hline & $\begin{array}{l}\text { The difference of real and expected monthly wages of the first } \\
\text { job }\end{array}$ & -0.838 & 0.643 & 2.313 \\
\hline & Same occupation of real and expected of the first job & -0.011 & 1.318 & 0.989 \\
\hline & Job tenure of the first job & $-0.966 * *$ & 0.457 & 0.381 \\
\hline & Types of mobility (shift to other province as reference point) & & & \\
\hline & Shift to the same city within province & -0.821 & 1.296 & 0.440 \\
\hline & Shift to other city within province & -0.076 & 6.242 & 1.079 \\
\hline & Constant & -4.066 & & \\
\hline & -2Loglikelihood & 45.452 & & \\
\hline & Cox \& Snell R Square & 0.651 & & \\
\hline & Nagelkerke R Square & 0.900 & & \\
\hline
\end{tabular}

$* * *, * *$ and $*$ indicates significance at thelevels of $1 \%, 5 \%$ and $10 \%$.

balancing the gain from further search against the loss. Workers may learn about better jobs or decide to change their types of work while employed, on-the-job seekers try to find out opportunities which can improve their utilities via job mobility against uncertain labor market. Job mobility of MFMWs is jointly determined by the features of time preference, search channels, and match qualityof the first job as the result of the gains weighing thecost, conversion probability of female labor workers can be summarized as follows:

$$
\ln \frac{P}{1-P}=\alpha X+e_{i}(1)
$$

Where, $Y$ is the conversionindicator for MFMWs, if converted, a value of 1 ; otherwise is $0 . \mathrm{P}$ is the transition probabilityfor rural female labor, it is given as

$$
P(Y=1)=\frac{\mathrm{e}^{\alpha X}}{1+e^{\alpha X}}
$$

$\alpha=\left(\alpha_{0}, \alpha_{1}, \alpha_{2} \ldots, \alpha_{n}\right)$ is the parameter vector, $X=\left(x_{1}, x_{2}, \ldots, x_{n}\right)$ is the vector of independent variables, including factors affecting time preference,job searching efficiencyand match quality.

Personal attributes include age, education, and job training situation. In particular, employment training is divided into 
training provided by firms, farmers' active participation in training schools, training provided by government agencies.

Family attributes, including the number of children of RMFM, whether their husbandsare migrant workers, are collected. The working sites of migrant husbands are divided into groups of the same city, different unit in the same city, and same unit and city.Job search channels include the ways of relatives and friends, the advertisement of TV and newspapers, government agencies and professional intermediaries. Job arrangements before entering into city is used to reflect the job search method.

Job tenure, the difference between real and expected wages, real and expected occupations, and salary for the first job are used as indicators of match quality. In this article, the relationship between real and expected wages is divided into three levels, -1 is when real wages is lessthan expected wages, real wages equal to theexpected wage of 0 ; actual wages greater than expected wage for 1 .

\subsection{Data collection and statistical description}

Unemployment data of rural migrants are not available in China. To examine the relationship between functioning of labor market and job mobility of rural female migrants, the field survey was conducted in February of 2012 at Fuliang County in Jingdezhen City of Jiangxi Province. Jiangxi Province is a traditional agricultural base and labor exportingprovince in China. Jingdezhen City is located in the northeast of Jiangxi Province. Jingdezhen Cityhas jurisdiction over 42 townships.

Fuliang County is chosen as study area due

to following considerations. Firstly, threeCeramic Industrial Parks near Jingdezhen Cityprovide an opportunity for rural labor transfer; secondly, the ratio of married women to total migrated population has significantly increased recently. In 2010, total migrant workers at Fuliang County were 29,835, including married women 6230, accounting for 20.9 percent ofmigrated population.

To eliminate the bias of sample selection, the survey sampled seven townshipsof Fuliang County among four categories, 1 percent ofhouseholds were selected as sampled population. Questionnaire consists of personal characteristics of married migrant women, family characteristics, job search channels and job characteristics of the first job.

In total, 196 MFMWs were interviewed. Among them, 129 migrant women did not change jobs, accounting for 65.8 percent.

\section{Regression analysis}

The microscopic mechanism of on-the-job search is important to examine factors responsible for the mismatch between jobs and rural floating population as a result of randomly assigned jobs.By using SPSS19.0, the determinants of job mobility of MFMWsare examined based on field surveyed data of 196 sampled subjects, the regressive result is given in Table 1.

The -2Loglikelihood, the Cox \& Snell R Square, and Nagelkerke R2indicate that the model has goodness of fit. The result of regression analysis shows that family reunion via working at the same firm or same city is the main purpose of rural female job mobility. The decision of job mobility is significantly affected match quality of MFMWs. The first job with lower payoffs and higher labor intensity will lead to higher work turnovers. Job tenure will reduce the job mobility due to the consideration of accumulated effect of human capitals by virtue of work experiences. The training from employers enriches human capital and lower job mobility accordingly. Individual participation in school training makes married female migrant workers change jobs much often. Job search channels and whether job has been arranged before female migrant workers entering into cities affect their decisions on job mobility.

\subsection{Match quality of the first job and job mobility}

Against a dual economy characterized by segmented labor market, more and more farmers have moved out of agriculture and worked in urban cities or towns at the secondary sector, which ischaracterized by low-paying jobs, few opportunities to advance, andunstable careers. In detail, 61.7 percent of individuals work in manufacture activities, it is labor-intensive industry with poor working conditionand, low wages, 112 individuals work for 8 to 9 hours daily, followed by subjects working 10 to 11 hours, subjects working 12 hours or more account for 10.2 percent. More women working longer hours with lower wages change jobs. Job mobility is a searching and matching process of leaving current jobs and seeking higher paid jobs, this happened in China. For all who changed jobs, there is an improvement in terms of monthly wage as a result of job mobility. According to the field survey, MFMWs who have changed jobs mainly engaged in informal sector, such as manufacturing(32.3 percent), wholesale and retail (28.6 percent), and catering services(49 percent), there is a strong reinforcement between workers' jobs and assigned occupations. Although the gap of monthly wages between changedand unchanged subjects is narrowed after job mobility, with a consideration of segmented labor market in China and a low bargaining power for unskilled workers, human capital factors have almost no effect on wage earnings of RMMWs engaged in informal sector. Human capital factors have almost no effect on wage earnings of RMMWs engaged in informal sector.

\subsection{Psychological factors and job mobility}

The psychological costsare important factors affectingjob mobility (Schultz 1990). According to the field survey, among all 196 subjects, 92 couples work in the same cities 
and firms with lower intention to convert jobs. Given much consideration to marital stability, most of the migrant women followed their husbands to work in the same unit or the same city; at the same time, work experience of their husbands can effectively reduce theirjob searchingcost and psychological costs. Working status of husbands rather than the number of children has significantly affected decisions on job mobility. However, the agesof children have significant impact on thedecision of job mobility of migrant women. Preschool kids aging from 1 to 5years old does not affect the decision of work conversion. In contrast, the number of kids aging at 6 to 10 years old will hinder job mobility of MFMWs. Education level, professional training of MFMWs and job mobility.

\subsection{Education level, professional training of MFMWs and job mobility}

Human capital refers to physical status, job skills, experience, or formal education. According to the filed survey, the average age of the subjects is 29.83 years old. The younger the employees with higher the educational levels are more likely to change jobs. Lack of knowledge and skills hinderrural farmers to enter urban formal sector. Wage growth across jobs due tochanges in the individual's human capital stock resulting from job mobility and losses of specific training incurred whenjob separation takes place.Frequency of job searching just determines the benefit of job mobility in response to the mismatch between employees and employers on wage levels and working relationship. This is proved by the change of average returns of job mobility with a rising times of job mobility. As a specific human capital investment (Sicherman 1990), different types of job-training of rural married women have different impacts on job mobility. Firm-specific training promotes job stability by providing dedicated skills, while professional training from private schools and government agencies accelerate job mobility.

\subsection{Job search channels, job arrangementand modes of job mobility}

The channels of job search influence the job mobility of rural married migrant woman. The survey shows that migrant workers mainly rely on traditional kinshipsand geopolitical networks to obtain jobs of poor working conditions, high work intensity and low payoffs. It is relatively shorter time for on-the job seekers to search jobs through career intermediaries and government agencies because of the advantage in information gathering and provision of career intermediary and the government agencies. Informal personal communication is particularly important because talking with someone who has worked for a prospective employer should be the best way, of finding out about the nature of a particular job. Women short of on-the-job experience in the pre-employment could obtain valuable information about the nature of the work and income and welfare, therefore, there is a lower tendency to job mobility. In contrast, rural married women organized by the government agencies are more likely to convert work.

\subsection{Working contract}

There is positive impact of job contract on wage growth, 65.3 percent ofsubjects signing a formal contract have wageshigher than $1600 \mathrm{RMB}$. With regard to the subjects without a formal contract, only 18.2 percent of have wages more than $1600 \mathrm{RMB}$. In segmented labor market, there is often an implicit agreement between employers and employees that fixes the money wage over some time period. Job contract is an insure mechanism to secure a stable employment relation between employees and employers, job tenure is longer for employers who signed job contracts. Signing a formal contract negatively affects the work conversion of rural married women, but not significantly.

\section{Conclusions}

The empirical analysis shows that working at the same firm or in the same city with her husband will enhance job stability, marital stability is the main purpose of job mobility of MFMWs. Mismatch reflected by shorter job tenure, the gap between real and expected wages, the skills and occupations poorly matched with the skill requirements of job openings should be responsible for the higher flowing frequency of on-the-job seekers. The age of kids along with migrant women will affect their job mobility, but not significantly. Meanwhile, a younger womanwith junior and high school education is more likely to change jobs, but subjects with education above the high school level remains stable.

Different job search channels affect the on-job-mobility of rural married women due to the match quality. The trust on relatives and relatively low information acquisition costs make more migrant women to get the first jobs via relatives and other social networks. Job search channels and whether job has been arranged or not before female migrant workers entering the city both affect job mobility. The first job with lower income and higher labor intensity measured by working hours will promote female migrant workers to change job.The gap of expected and actual wages affects the conversion of labor, higher income is expected to be induced conversion of married women direct motives.

\section{References}

[1] Holzer, H. 1987. Informal job search and black youth unemployment. American Economic Review 77: 446-452.

[2] Schultz, T.W. 1990. Human Capital Investment and Urban Competitiveness. Beijing: Beijing economics Institute Press. (In Chinese). 
[3] Sicherman, N. \& Galor, O. 1990. A Theory of Career Mobility, Journal of Political Economy98: 169-192.

[4] Su, Q. \&Liu, H. 2003. An empirical study on Chinese rural women labor mobility. Issues in Agricultural Economy2003 (4):39-43. (In Chinese).
[5] Yao, X.G. \& Hu, F.X. 2009. A literature review on Chinese rural women labor mobility, Productivity Research 17:189-192. (In Chinese).

[6] Zhou, L.L. 2008. A literature review on labor shortage in 2007. Journal of Coastal Enterprises and Technology 2008 (1): 184-186. (In Chinese) 